\title{
Potential of some carotenoids in two recent sediments of Kiel Bight as biogenic indicators of phytodetritus
}

\author{
Doris Abele-Oeschger
}

Universität Bremen, Meereszoologie, Fachbereich 2, Bürgermeister-Smidt-Str. 20, W-2850 Bremerhaven, Germany

\begin{abstract}
Carotenoids are routinely used as biogenic markers for plant debris in the marine environment. But, like the chlorophylls, carotenoids suffer chemical alteration and even hydrolysation to colourless endproducts when detritus is metabolized by animals and bacteria in the water column. This study investigates the stability of pigments after deposition in surface sediments. In a laboratory experiment using oxic sediment, the carotenoid lutein exhibited greater stability against chemical and microbial breakdown than chlorophyll $a$, which has a half-life of only 3 wk under oxic conditions. In situ investigations in anoxic mud sediments in Kiel Bight, Germany, showed rapid disintegration of polar xanthophylls and chloropigments. $\beta$-Carotene and lutein were relatively stable in anoxic sediment. Data from a 1 yr field study at 2 stations in Kiel Bight are reported as an example of the applicability of carotenoid pigments as biogenic markers in sediments. Advective transport of macrophyte debris was investigated by measuring the concentration of lutein in different sediments on a down-slope transect. Lutein exhibited a pattern of slowly increasing red macrophyte input to the muddy sediments, starting in autumn and continuing through winter; but it was not detected in shallow sand sediments near the growth sites of the algae. Fucoxanthin and peridinin were found in both muddy and sandy sediment, reflecting sedimentation events resulting from transport of phytoplankton from the water column.
\end{abstract}

\section{INTRODUCTION}

One of the major interests in benthic ecology lies in calculating the turnover of organic carbon in marine sediments. This includes deposition and accumulation of organic detritus containing carbon, as well as consumption and respiration by organisms, and carbon loss in to the water column through resuspension of the sediment. In coastal areas like Kiel Bight, Germany, horizontally transported macrophyte debris appears to provide a major source of organic input to the sediment (Liebezeit 1986, Wefer et al. 1987, Abele 1988, Graf 1989 b) but the amount is difficult to calculate. Most crop-forming macrophytes are perennial and disintegration of the thalli is a long-lasting event compared with the sudden breakdown of phytoplankton blooms. The major input of macroalgal carbon to Kiel Bight occurs in autumn and winter, when storms transport macrophytes torn loose from their hard substrate into deep channels (Schomann 1977), where they accumulate and are finally incorporated into the sediment by the bottom fauna. Kiel Bight is a shallow coastal transi- tion area between the Kattegat and the Baltic proper. Its macrophytobenthos is dominated by red algae of the genera Phycodris and Phyllophora. Extended populations of brown seaweeds like the kelp Laminaria sp. and Fucus vesiculosus have been significantly reduced in biomass during the past $25 \mathrm{yr}$ (Breuer \& Schramm 1988).

Pigments may be used to trace the transport and deposition of macrophyte carbon in water samples (Lehmann 1981, Gieskes \& Kraay 1983, 1984, 1986, Klein \& Sournia 1987, Wright \& Jeffrey 1987), as well as in marine sediments (Watts et al. 1975, Züllig 1982 , Repetã \& Gagosian 1987, Riaux-Gobin et al. 1987. Abele 1988, Abele \& Schramm 1989). Chlorophyll derivatives may indicate specific degradation pathways of algal material in the water column (SooHoo \& Kiefer 1982, Kleppel \& Pieper 1984, Downs \& Lorenzen 1985), where the effect of zooplankton grazing on plant pigments in the water column is currently being investigated (Repeta \& Gagosian 1981, 1982, Downs \& Lorenzen 1985, Klein et al. 1986, Nelson 1989). Chlorophyll $a$, which is routinely used as biomass para- 
meter in phytoplankton studies, may be almost entirely degraded to colourless breakdown products by copepod grazing (Conover et al. 1986, Wang \& Conover 1986) and pheophorbide is not necessarily the main product in this process. According to Repeta \& Gagosian (1982), half of the xanthophyll fucoxanthin present in the water column is hydrolysed in the guts of zooplankton. Less information is available on carotenoid alteration after deposition in the sediment surface. Repeta \& Gagosian (1987) analyzed surface sediment from the Peru upwelling area. They found that the 5,6epoxide function in the structure of fucoxanthin, peridinin, and diadinoxanthin enhances these pigments' degradation to colourless endproducts after deposition. Carotenoids without epoxide functions seemed more resistant to the various processes after deposition.

In the present paper, carotenoids were analysed in an erosive, shallow-water sand sediment and a deep mud sediment of Kiel Bight. These pigments were chosen as markers for different sources of primary producers, with the aim of distinguishing between the vertical flux of sedimenting phytoplankton and horizontally transported macrophyte debris in the sediment. The quantitatively important markers chlorophyll $a$, lutein and fucoxanthin were tested with regard to stability after deposition in surface sediments. Shorttime degradation processes were measured in a laboratory experiment, while the long-term fate of the markers in the sediment surface was investigated in an anoxic sediment core.

\section{MATERIAL AND METHODS}

Laboratory experiment on pigment degradation. To study pigment degradation in the sediment surface under laboratory conditions, sediment cores of $10 \mathrm{~cm}$ length and $20 \mathrm{~cm}^{2}$ surface area were collected in $17 \mathrm{~m}$ water depth from a submerged slope (Gabels Flach, $\mathrm{GF})$ in western Kiel Bight $\left(54^{\circ} 32.7^{\prime} \mathrm{N} ; 10^{\circ} 16.6^{\prime} \mathrm{E}\right)$ in June 1986. The cores were collected with a box corer to keep sediment stratigraphy intact. The sediment consisted of muddy sand with an organic carbon content of $0.45 \%(\mathrm{C} / \mathrm{N}$ measurements) and pigment concentrations of $<5 \mu \mathrm{g} \mathrm{g}^{-1}$ dry wt sediment (measured by high performance liquid chromatography, HPLC). For the incubation experiments, cores were placed into a $2000 \mathrm{l}$ aquarium filled with seawater collected at a depth of $15 \mathrm{~m}$ at the same station. The aquarium was kept at $10^{\circ} \mathrm{C}$ in the dark during the $10 \mathrm{wk}$ experiment. Detritus for the experiment was made from fresh red algal material, which was washed in filtered seawater and visually searched for epifauna. Subsequently, the material was mechanically ground and sieved through a $1000 \mu \mathrm{m}$ mesh. The fraction smaller than $1000 \mu \mathrm{m}$ was kept in filtered seawater for $3 \mathrm{~d}$ in the dark to simulate a leaching process. After $3 \mathrm{~d}$ the material was sieved through $250 \mu \mathrm{m}$ mesh and the size-fraction between 250 and $1000 \mu \mathrm{m}$ used in the experiment. This detritus had a fucoxanthin content of $3.2 \mu \mathrm{g} \mathrm{g}^{-1}$ dry wt due to an epiphytic diatom flora, which could not be removed by washing. On a $20 \mu \mathrm{m}$ plankton gauze (to prevent animal immigration from the core underneath) $750 \mathrm{mg}$ of detritus was mixed with $5 \mathrm{~cm}^{3}$ sand sediment which had been depleted of its macro- and meiofauna by freezing in liquid nitrogen. This mixture was placed on top of each sediment core (Fig. 1). The pigment concentrations in the sediment detritus mixture were meas-

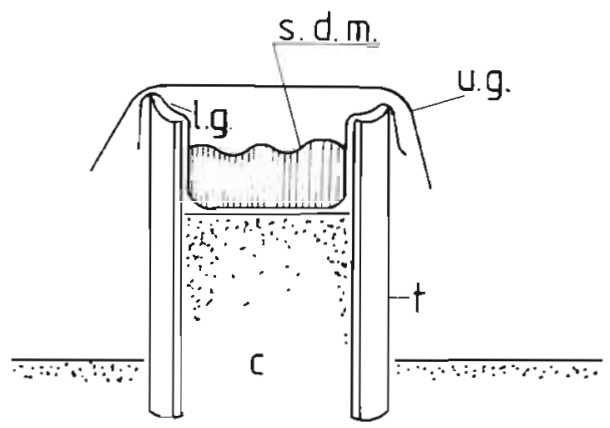

Fig. 1 Sediment core used in the incubation experiment. c core; t: tube corer; u.g.: upper gauze; l.g.: lower gauze; s.d.m.: sediment-detritus mixture

ured after 1, 2, 3, 6 and $10 \mathrm{wk}$. The sediment was extracted with a solution of acetone/methanol (v/v 3:1). Pigments were analyzed by HPLC. On each sampling date, duplicate samples were analysed for chlorophyll a, lutein, and fucoxanthin.

In situ sediment sampling. Sediments were collected with a Van Veen grab at the GF slope between March 1986 and April 1987. In $12 \mathrm{~m}$ water depth (GF: $54^{\circ} 32.0^{\prime} \mathrm{N} ; 10^{\circ} 18.5^{\prime} \mathrm{E}$ ) the sediment consisted of coarse sand with a water content of $20 \%$ and an organic carbon of $0.3 \%$.

In $19 \mathrm{~m}$ water depth (GF: $54^{\circ} 33.4^{\prime} \mathrm{N} ; 10^{\circ} 13.94^{\prime} \mathrm{E}$ ) the sediment consisted of sandy mud containing up to $45 \%$ of the small grain size fraction ( $<63 \mu \mathrm{m}$ in diameter) on a dry weight basis. The organic content of this sediment was much higher (about $4 \%$ of sediment dry wt) and the water content was $60 \%$. After retrieval, subsamples were taken with plexiglas tubes $(5 \mathrm{~cm}$ diameter). A $1 \mathrm{~cm}$ surface slice from each core was immediately frozen at $-18{ }^{\circ} \mathrm{C}$ until extraction. Each value was calculated as the mean of 3 parallel core samples.

To investigate pigment degradation in the upper part of the sediment column, vertical pigment profiles were measured in cores of $25 \mathrm{~cm}$ length collected from $28 \mathrm{~m}$

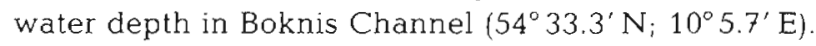
This station represents the maximum depth in Kiel 
Bight. To obtain undisturbed cores, a Reineck box corer was used. Sediment collected at this station consisted of fine-grained silt and clay, with $95 \%$ of the particles smaller than $63 \mu \mathrm{m}$ in diameter. The proportion of organic material was as high as $4.5 \%$ (Balzer 1986), and the sediment porosity, calculated from the absolute water content, was 0.85 (Abele 1988). Due to frequent periods of anoxia, the sediment of this station is nearly free from bottom fauna, and depth profiles are practically unaffected by bioturbation. A sedimentation rate of $1.4 \mathrm{~mm} \mathrm{yr}^{-1}$ for this area has been reported by Erlenkeuser et al. (1974), but higher rates of up to $3.1 \mathrm{~mm} \mathrm{yr}^{-1}$ were calculated by Balzer (1986) (Pb-210 and C-14 studies) in channel sectors where topography and bottom currents result in horizontal down-slope transport of organic matter. The upper sediment layer $(0$ to $1 \mathrm{~cm})$ consists of mixed sediment of different ages (i.e. recently deposited and older resuspended) - on the whole relatively new loosely packed material. Lack of macrofauna colonization at this station delays the incorporation of freshly sedimented material. In the laboratory, cores were sectioned into $1 \mathrm{~cm}$ thick slices, which were immediately extracted. Acetone extracts were kept frozen at $-20^{\circ} \mathrm{C}$ until analysis.
Pigment extraction. Wet sediment was extracted with acetone/methanol (v/v 3:1) at room temperature in the dark for $1 \mathrm{~h}$. After centrifugation, extracted pigments were decanted and the sediment extracted again with fresh solvent. The sediment residue was dried for $2 \mathrm{~d}$ at $60^{\circ} \mathrm{C}$ to recalculate the pigment content on a sediment dry weight basis.

Extraction solvents were removed from aqueous extract by vacuum evaporation. From the water residue, pigments were extracted into a hexane medium containing 5 to $10 \%$ acetone.

The aqueous extract was re-extracted in hexane to remove the water-soluble fraction. Hexane was vacuum-evaporated. Pigments were redissolved in methanol, and analysed by reversed phase HPLC. Two chromatograms from $12 \mathrm{~m}$ and from $19 \mathrm{~m}$ water depth from GF are presented in Fig. 2, as examples.

Pigment separation by High Performance Liquid Chromatography. Pigments were separated by gradient elution, with a $5 \mu \mathrm{m}$ Spherisorb ODS II HPLC column $(250 \times 4 \mathrm{~mm})$. Solvent $A$ consisted of $\mathrm{H}_{2} \mathrm{O}$ / methanol ( $v / v 30: 70)$, Solvent B of 10\% methanol. Ionpairing reagent was omitted. Linear gradient elution started with $20 \%$ Solvent A and ended with 100\%
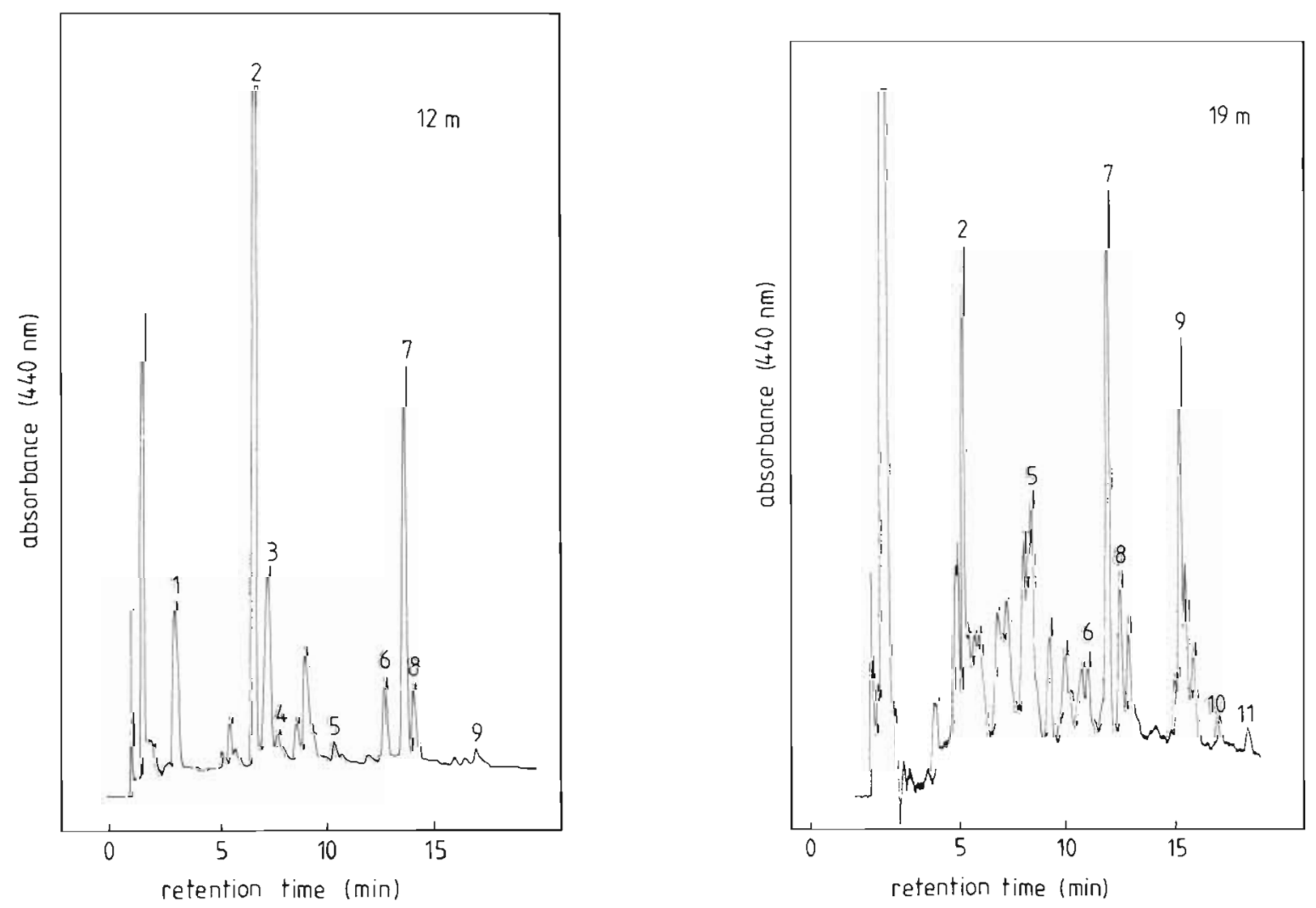

Fig. 2. HPLC-chromatograms of surface sediment extracts from $12 \mathrm{~m}$ sand sediment and $19 \mathrm{~m}$ mud sediment from Gabels Flach, Kiel Bight (0 to $1.5 \mathrm{~cm})$. 1: Chlorophyll $c_{i} 2$ : fucoxanthin; 3: neoxanthin; 4: violaxanthin; 5 : lutein/zeaxanthin; 6 : chlorophyll $b$; 7: chlorophyll $a_{i}$ 8: echinenone; 9: $\beta$-carotene; 10: pheophytin $a_{;} 11$ : unknown pheophytin-like pigment 
Solvent B after 15 min followed by an isocratic phase of $100 \%$ Solvent B over $15 \mathrm{~min}$. The flow was $1.6 \mathrm{ml}$ $\mathrm{min}^{-1}$. All solvents were high purity grade.

The HPLC consisted of a Rheodyne 7125 injector equipped with a $100 \mu$ loop, 2 Constametric pumps (Milton Roy, LDC), and a gradient master with an $8 \mu \mathrm{l}$ mixing cell. Absorbance was recorded with a Shimadzu UV-Vis Spectrophotometer at $436 \mathrm{~nm}$ and at $475 \mathrm{~nm}$. Chlorophyll fluorescence was measured with a Schoeffel 970-fluorimeter at $390 \mathrm{~nm}$ excitation, a 7-51 primary Corning filter and a $580 \mathrm{~nm}$ cut-off filter for emission. Identification of peaks was done by HPLC and also Thin Layer Chromatography (TLC) co-chromatography with standard carotenoids provided by Hoffmann La Roche, Research Laboratories, Basel, Switzerland (Table 1). Quantification was done with authentic standards provided by La Roche. Direct photometric measurement of single carotenoids, separated on TLC plates, was carried out using the extinction coefficients $\left(\varepsilon^{l \%}\right)$ given by Mantoura \& Llewellyn (1983). Absorption maxima of isolated compounds (TLC methods 1 and 2) are listed in Table 1.

Pigment separation by Thin Layer Chromatography. Merck TLC Silica plates were used for pigment separation using a developing solvent consisting of $40 \%$ acetone in hexane (TLC1). As the xanthophyll isomers lutein and zeaxanthin could not be separated by the applied HPLC system, part of each sample, including all sediment samples, was processed according to a TLC technique after Björnland \& Aguilar Martinez (1976). Chlorophylls were degraded on alkaline plates and retained at the baseline, while ciscarotenoids and isomers $\beta$ - $\beta$-carotene and $\beta-\varepsilon$ carotene, or lutein and zeaxanthin, could be satisfactorily separated (TLC2). Pigments were recovered by scraping the plate and eluting with acetone or hexane. Re-eluted individual components were quantified either by re-injection into HPLC or by calculation from the visible spectra (Abele 1988).

\section{RESULTS}

\section{Degradation experiment}

The percentage diminution of the markers chlorophyll $a$, lutein and fucoxanthin from red macrophyte detritus in sandy bottom surface sediment from $12 \mathrm{~m}$ depth at Gabels Flach incubated for $10 \mathrm{wk}$ in an aquarium is shown in Fig. 3. As animals, including meiofauna, had been removed, the breakdown of pigments was attributed to chemical and microbial processes. Initial values were calculated from pigment content of the added red algal detritus. The first measurement

Table 1 Pigment identification, extinction coefficient $\left(\varepsilon^{1 \%}\right)$ and chromatographic methods. $\mathrm{r}_{\mathrm{f}}$ : retention factor on alkaline plates (TLC2)

\begin{tabular}{|c|c|c|c|c|c|c|c|c|}
\hline \multirow[t]{2}{*}{ Component } & \multirow{2}{*}{$\begin{array}{c}\text { Absorption } \\
\text { maxima }^{a} \\
\lambda(\mathrm{nm}) \\
\text { (solvent) }\end{array}$} & \multirow{2}{*}{$\begin{array}{l}\text { Observed } \\
\text { maxima } \\
\lambda(\mathrm{nm}) \\
\text { (solvent) }\end{array}$} & \multirow{2}{*}{$\begin{array}{c}\varepsilon^{1 \%} \\
440 \mathrm{~nm}\end{array}$} & \multicolumn{5}{|c|}{ Co-chromatography with authentic standard } \\
\hline & & & & HPLC1 & HPLC2 & HPLC3 & TLC1 & TLC2 \\
\hline Chlorophyll a & $\begin{array}{l}410,430,663 \\
(90 \% \text { acetone) }\end{array}$ & $\begin{array}{l}410,430,663 \\
\text { (acetone) }\end{array}$ & 687 & + & & & $\begin{array}{l}+ \\
+\end{array}$ & \\
\hline Chlorophyll $b$ & $\begin{array}{l}595,642 \\
\text { (ether) }\end{array}$ & $\begin{array}{l}594,692 \\
\text { (acetone) }\end{array}$ & 853 & + & & & & \\
\hline Chlorophyll $c$ & $\begin{array}{l}452,586,634 \\
\text { (methanol) }\end{array}$ & $\begin{array}{l}452 \\
\text { (acetone) }\end{array}$ & 3460 & & & & & \\
\hline Pheophytin a & $\begin{array}{l}533,609,667 \\
\text { (acetone) }\end{array}$ & & 713 & & & & & \\
\hline Chlorophyllide & $\begin{array}{l}410,430,663 \\
\text { (acetone) }\end{array}$ & & 687 & & & & & \\
\hline Lutein & $\begin{array}{l}(418), 444,474 \\
\text { (methanol) }\end{array}$ & $\begin{array}{l}(425), 448,476 \\
\text { (acetone) }\end{array}$ & 2393 & + & + & + & & $r_{f}: 0.75$ \\
\hline Zeaxanthin & $\begin{array}{l}445,475 \\
\text { (methanol) }\end{array}$ & $\begin{array}{l}450,481 \\
\text { (methanol) }\end{array}$ & 2000 & + & + & + & & $\mathrm{r}_{\mathrm{f}}: 0.45$ \\
\hline$\beta$-Carotene & $\begin{array}{l}449,475 \\
\text { (ethanol) }\end{array}$ & $\begin{array}{l}448,(474) \\
\text { (acetone) }\end{array}$ & 2210 & + & + & + & & \\
\hline Peridinine & $\begin{array}{l}467 \\
\text { (methanol) }\end{array}$ & & 1126 & + & + & + & & \\
\hline Fucoxanthin & $(426), 449(456)$ & 448 & 1016 & + & + & & + & \\
\hline
\end{tabular}




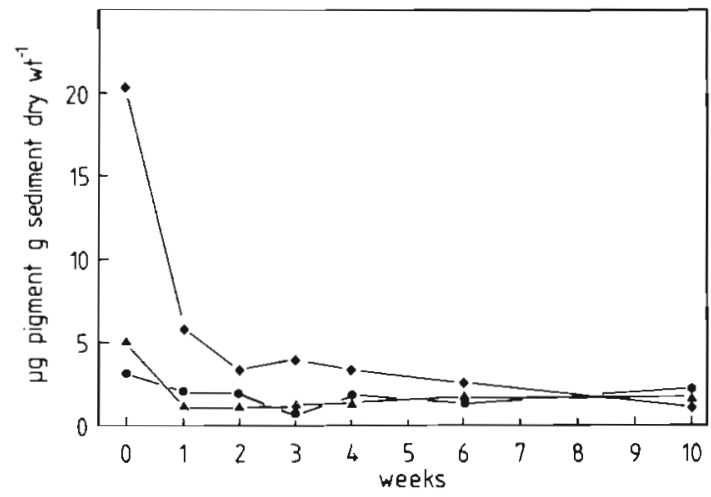

Fig. 3. ( $\bullet$ Chlorophyll $a,(\star)$ lutein, and $(\bullet)$ fucoxanthin degradation in oxygenated surface sediment. Data in $\mu \mathrm{g} \mathrm{g}^{-1}$ dry wt in the 0 to $2 \mathrm{~cm}$ sediment layer. Data originate from a $10 \mathrm{wk}$ laboratory experiment

1 wk after addition of the detritus displayed only low chlorophyll $a$ and lutein recovery in the $5 \mathrm{~cm}^{3}$ of surface sediment. In contrast, recovery of fucoxanthin was $60 \%$ of the added amount. If one outstandingly low fucoxanthin value (Week 3 ) is left aside, no significant change in the fucoxanthin and lutein concentrations could be observed between Week 1 and Week 10 , while chlorophyll a diminished slowly and was below $10 \%$ of the initially added amount after $10 \mathrm{wk}$.

Degradation of fucoxanthin, lutein and chlorophyll a in oxic surface sediment, starting at Week 1 , is a first order reaction:

$$
-\frac{\delta S}{\delta t}=k[S]
$$

where $\delta S=$ the decrease in pigment concentration per unit time $(\delta t) ; k=$ the first order reaction constant; and $[\mathrm{S}]=$ the residual pigment concentration at time $t$. A linear correlation $(r=0.99)$ between weekly pigment degradation $\left(-\delta S w^{-1}\right)$ and the amount of residual pigment at time $t\left([S]_{t}\right)$ was found in the case of chlorophyll a. A half-life of $3 \mathrm{wk}$ was calculated for chlorophyll $a$ in oxygenated sand sediment under dim light conditions and in the absence of detritus-feeding bottom fauna. Correlation was less strong for fucoxanthin $(\mathrm{r}=0.77)$, while no correlation existed for the lutein measurements $(r=-0.25)$.

\section{Pigment distribution in a sediment profile}

Vertical pigment profiles were measured in an anoxic sediment core from Boknis Eck Channel $(28 \mathrm{~m}$ water depth) and revealed pronounced differences in the pigments' stability (Fig. 4). Rapid degradation of chlorophyll $a$ and $b$ and of pheophytin a occurred after deposition in the 0 to $2 \mathrm{~cm}$ layer, while concentrations of the 2 carotenoids lutein and $\beta$-carotene changed less within the upper $6 \mathrm{~cm}$. In the 5 to $6 \mathrm{~cm}$ sediment layer, $100 \%$ of the $\beta$-carotene and $70 \%$ of the lutein surface concentration were still present, reflecting a homogeneous zone in the upper $6 \mathrm{~cm}$ sediment (Fig. 4). The concentration of fucoxanthin decreased rapidly within the upper $2 \mathrm{~cm}$, thus resembling the profiles of the chloropigments.
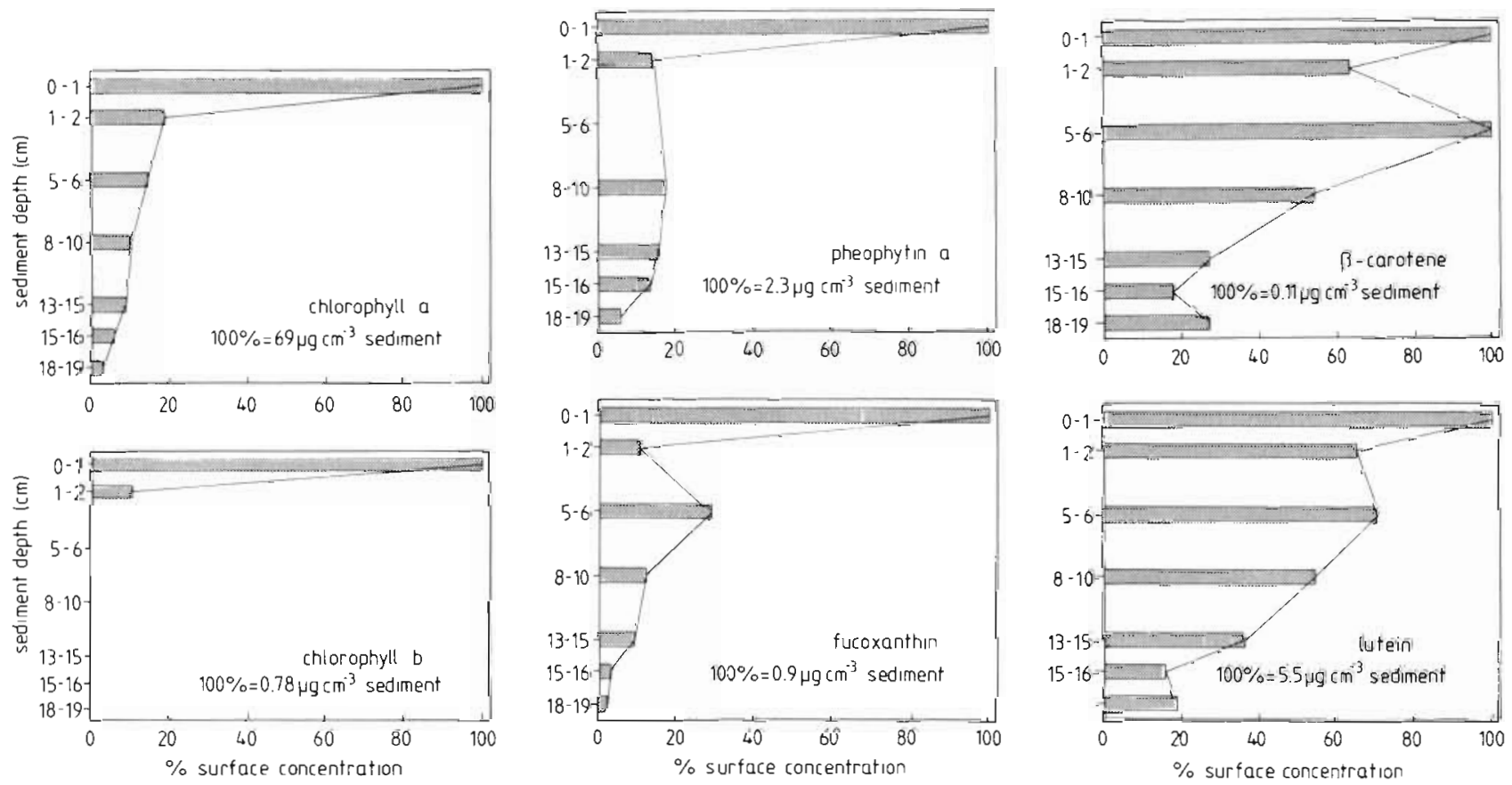

Fig. 4. Concentration/depth profiles of marker pigments in an anoxic sediment core from Boknis Eck Channel collected in September 1986. Values in \% of surface concentration 
Surface concentrations were between 2 and $7 \mu \mathrm{g}$ $\mathrm{cm}^{-3}$ of wet sediment for chlorophyll $a$, lutein, and pheophytin $a_{1}$ and below $1 \mu \mathrm{g} \mathrm{cm}^{-3}$ for the other pigments.

\section{Seasonal variations of pigment concentrations in recent sediments}

Fig. 5 shows seasonal changes in chlorophyll a concentrations in the sediment surface at 2 stations at Gabels Flach: $12 \mathrm{~m}$ sand and $19 \mathrm{~m}$ muddy sand. The 2 sites were about $5 \mathrm{~km}$ apart.

Chlorophyll a concentrations were much higher in the $19 \mathrm{~m}$ sediment than in the $12 \mathrm{~m}$ sediment. Concentration maxima found at the $12 \mathrm{~m}$ station at the end of June, and also during October and November, ap-

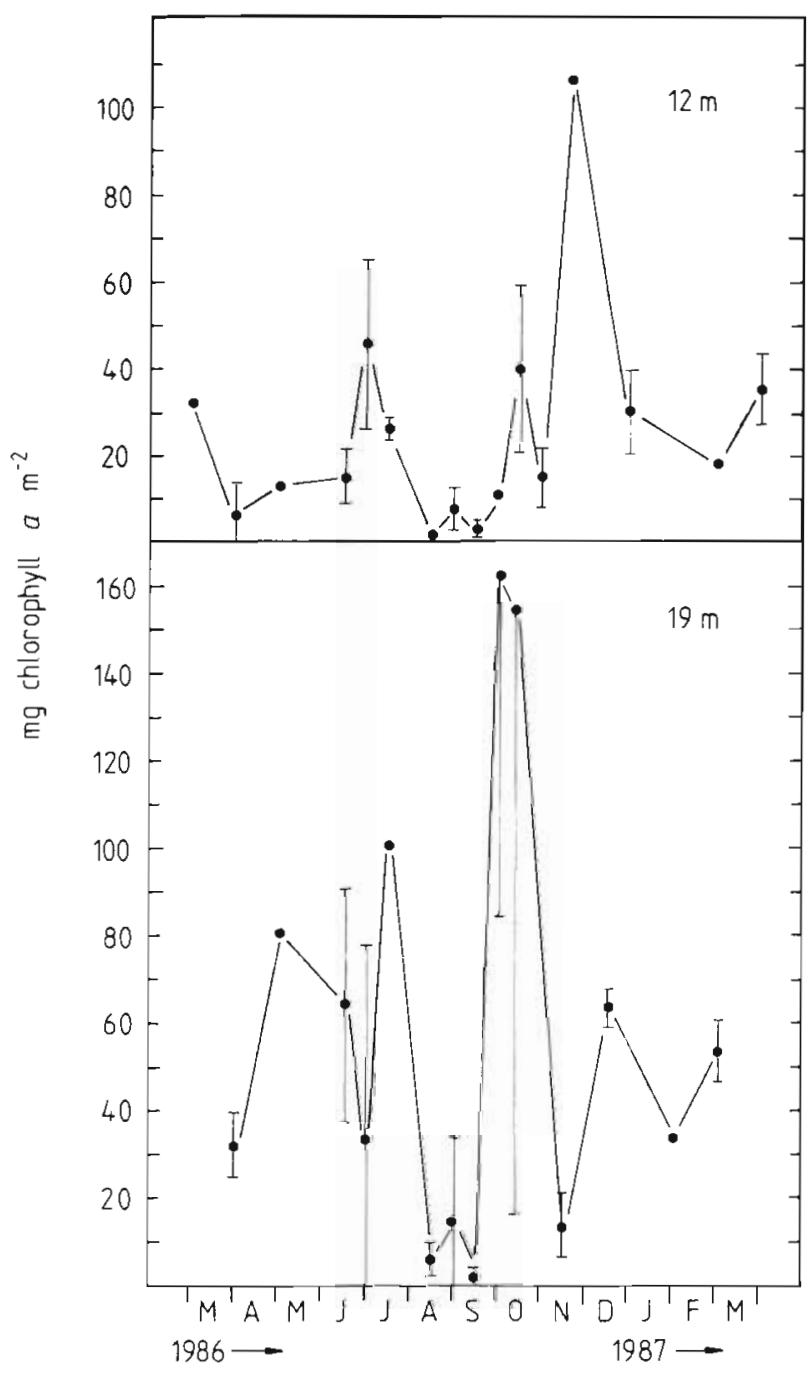

Fig. 5. Chlorophyll a concentrations in the 0 to $1 \mathrm{~cm}$ sediment layer at 2 stations ( $12 \mathrm{~m}$ and $19 \mathrm{~m}$ ) between April 1986 and March 1987 peared in $19 \mathrm{~m}$ water depth with a delay of 1 to $2 \mathrm{wk}$. In the sand sediment of the $12 \mathrm{~m}$ station, chlorophyll a (Fig. 5) and fucoxanthin (Fig. 6) were quantitatively dominating. Fucoxanthin concentrations were low at the end of March and increased in May. In June a simultaneous peak of the pigments chlorophyll $a_{\text {, }}$

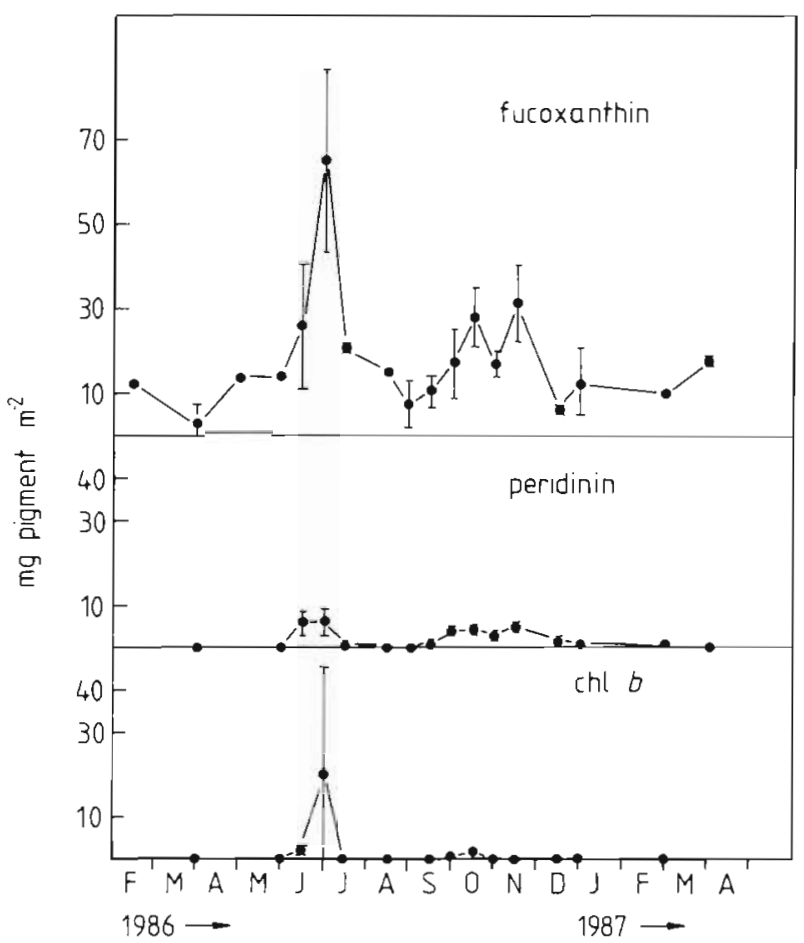

Fig. 6. Pigment markers in the sediment surface $(0$ to $1 \mathrm{~cm})$ of the $12 \mathrm{~m}$ sand station between April 1986 and March 1987

fucoxanthin, and peridinin occurred. Coarse sandy sediments in shallow waters provide ideal substrates for benthic diatoms containing the xanthophyll fucoxanthin as accessory pigment. This caused elevated fucoxanthin concentrations during spring and summer. Distinct events like sedimentation of more than $2 \times 10^{6}$ cells $\mathrm{m}^{-2} \mathrm{~d}^{-1}$ of Skeletonema costatum in June 1986 (Sommer unpubl.) could still be measured as a fucoxanthin peak above the microphytobenthos background concentration. Two autumn phytoplankton blooms, characteristic for the Kiel Bight area (Smetacek et al. 1984), were measured as distinct chlorophyll a peaks in the surface sediment at the $12 \mathrm{~m}$ sand station during October and November 1987 (Fig. 5). These sedimentation events appeared less pronounced in the fucoxanthin (diatoms) and peridinin (dinoflagellates) markers from the same stations. In diatom cultures containing several different species (Abele unpubl.) the fucoxanthin content amounted to about half the chlorophyll a content. During the autumn bloom, fucoxanthin: chlorophyll a ratios measured in the sediment surface 
were lower as compared to the diatom cultures, indicating the presence of algae groups contributing to the chlorophyll a pool, while not containing fucoxanthin. Small quantities of chlorophyll $b$ could be measured at the $12 \mathrm{~m}$ station during summer (Fig. 6).

In $19 \mathrm{~m}$ water depth (Fig. 7) the variety of pigments and of breakdown products was large compared to the $12 \mathrm{~m}$ sand sediment (Fig. 6). Concentrations of lutein, zeaxanthin and violaxanthin were significant in the mud sediment of this station. Distinct maxima in the concentration of zeaxanthin were observed in June, September and November 1986. In January and February 1987, when lutein concentrations were high, the amount of measurable zeaxanthin was low, around 10 $\mathrm{mg} \mathrm{m}^{-2}$ surface sediment, in a $1.5 \mathrm{~cm}$ thick sediment surface layer (Fig. 7). Lutein concentrations at the $19 \mathrm{~m}$ station were minimal during spring and summer 1986. The lowest concentration was found during August and September 1986. Starting in October 1986 the amount of lutein in the upper sediment layer steadily increased and a maximum was reached in December 1986. At the end of January 1987 a storm resuspended the overlying fluffy sediment, resulting in a subsequent diminution of lutein and zeaxanthin concentrations. Resuspension of sedimented detritus may have accelerated further degradation of the material, which also may have affected the pigments it contains. Lutein concentrations decreased slightly but were still significantly above summer levels (Fig. 7).

Chlorophyll $b$ values in the sediment were low during most of the measurement period. High values in the autumn and winter of 1986 with high standard deviation reflect patchy distribution of seagrass detritus (Fig. 7).

\section{DISCUSSION}

The application of carotenoids as biogenic markers for organic matter in marine sediments requires knowledge on the geochemical stability of these compounds. In what types of sediment are pigments preserved, and, conversely, what geochemical conditions enhance their degradation? In this paper degradation of pigments, frequently used as biogenic markers for plant detritus in marine environmental studies, was studied in oxic and anoxic surface sediments.

\section{Pigment degradation in oxic sediment}

The discrepancy in concentrations between the calculated input and the first actual measurement after $1 \mathrm{wk}$ is large and must be ascribed at least partially to loss of material from the core surfaces during experiment set up.

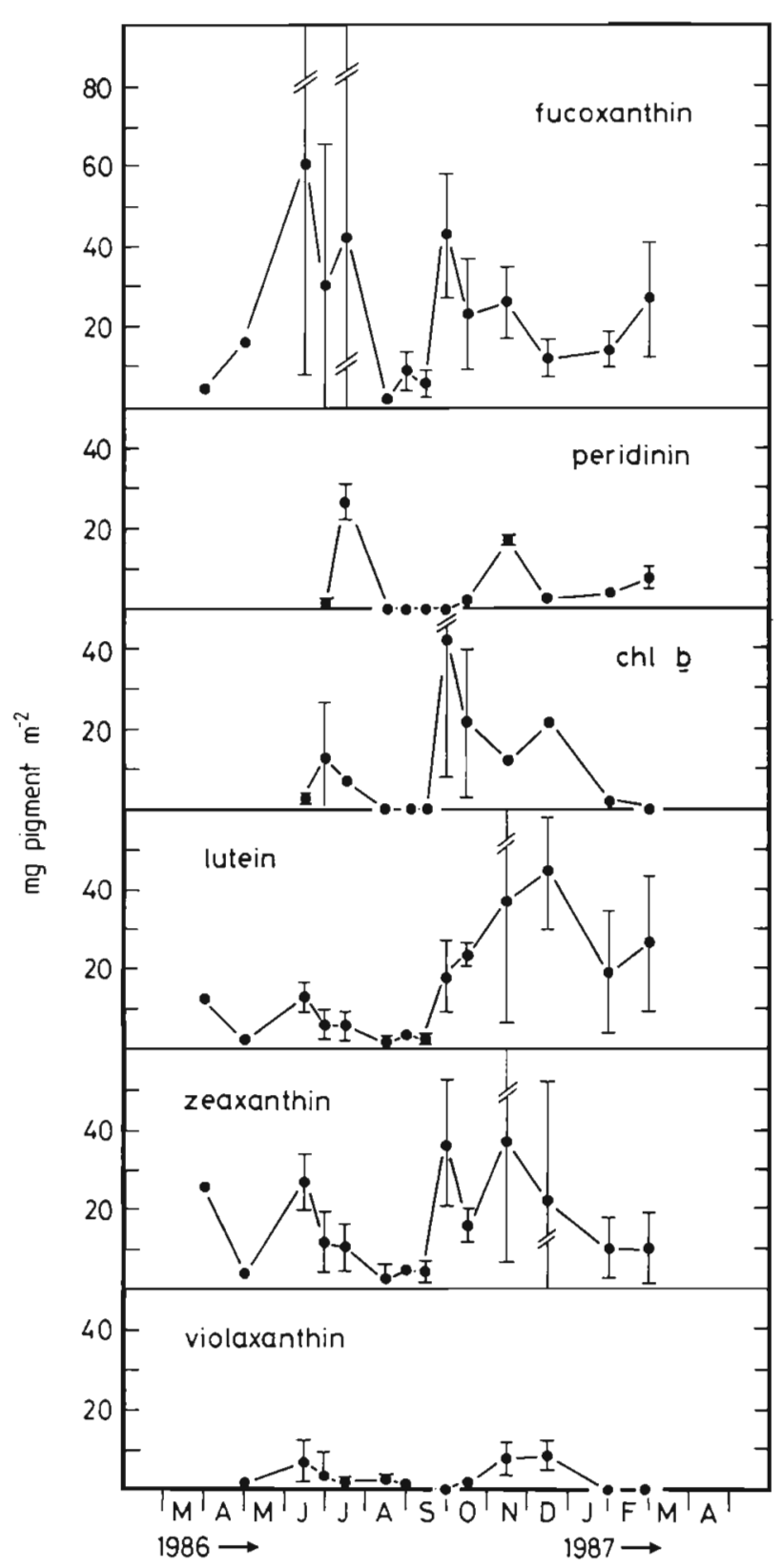

Fig. 7. Pigment markers in the sediment surface $(0$ to $1 \mathrm{~cm})$ of the $19 \mathrm{~m}$ mud station between April 1986 and March 1987

After Week 1, the concentration of chlorophyll a decreased steadily with time. Graf (1989a), investigating the sediment of a deep-sea plateau off the Norwegian continental margin, found that sedimented chlorophyll was $50 \%$ metabolised 1 mo after sedimentation. This indicates that a half-life of $3 \mathrm{wk}$, found for chlorophyll a breakdown under the experimental conditions described, beginning after $1 \mathrm{wk}$, is a realistic value. The percentage of lutein recovery per $\mathrm{mg}$ organic carbon in the sediment-detritus mixture even showed a slight increase towards the end of the experiment. This does not reflect an increase of the absolute 
lutein amount but rather the fact that lutein was indeed stable over these $10 \mathrm{wk}$, while there was a loss of organic material from the incubated sediment-detritus mixture.

\section{Pigment degradation in anoxic sediment}

Pigment profiles as shown in Fig. 4 can be subdivided into 2 regions. The upper $6 \mathrm{~cm}$ is well-mixed sediment with a $1 \mathrm{~cm}$ layer of freshly sedimented matter on top. Calculated from an accumulation rate of $1.4 \mathrm{~mm} \mathrm{yr}^{-1}$ (Erlenkeuser et al. 1974) for the Boknis Eck area, this $6 \mathrm{~cm}$ layer integrates a time of 35 to $40 \mathrm{yr}$. Sediment mixing is, at this station, caused by resuspension and resedimentation of the upper loosely packed fine-grained sediment by water movement through the channel. Markers, labile to light and oxygen, will clearly be degraded upon repeated cycling through the water column. Therefore, high concentrations of fucoxanthin and chlorophyll $a$ in the 0 to $1 \mathrm{~cm}$ horizon mark recently sedimented matter on the sediment surface.

Beneath the 0 to $6 \mathrm{~cm}$ mixed layer, sediment stratigraphy becomes stable. Decreasing vertical concentration profiles of lutein and $\beta$-carotene may be assigned to steady chemical and microbial degradation, if a constant input of lutein-containing material is assumed for the last 100 to $150 \mathrm{yr}$. If, in contrast, we attribute increasing lutein surface concentrations to an increasing input of red macrophyte material during the past years, we must assume that lutein is a stable marker. Then the lutein profile in Fig. 4 implies red macrophyte input to be twice as high in present times compared to the input $100 \mathrm{yr}$ ago. Other markers, like iodine, contained in red algal material, should be analysed in sediment profiles to verify this second possibility. If lutein is considered stable, this would offer further proof for eutrophication processes leading to increased macroalgal growth in Kiel Bight during the past decades. Breuer \& Schramm (1988) reported significant changes in macroalgal vegetation during the past years. According to their investigations, belts of brown seaweeds (Laminaria and Fucus) abundant in 0 to $12 \mathrm{~m}$ water depth in Kiel Bight 20 yr ago have been replaced by red algae Phyllophora truncata and Phycodrys rubens. These species are also dominating the sublittoral vegetation down to $20 \mathrm{~m}$ water depth. This shift in the vegetation in favour of red seaweeds, which are dislocated by storm events and transported advectively as detritus mats into the deeper parts of Kiel Bight's channel system, may explain the elevated lutein measurements within the upper parts of the sediment profile.

Laboratory experiment and sediment core analysis correspondingly showed that fucoxanthin and the chlorophylls $a$ and $b$ are short-lived markers reflecting recent phytoplankton sedimentation events. Labile oxygen functions like ester bonds and 5,6-epoxides in these molecules are quickly altered in the water column and in surface sediments (Repeta \& Gagosian 1987, 1984, Nelson 1989). Our investigations support the reported breakdown of these markers after deposition in the sediment regardless of whether under anoxic conditions. In contrast, the xanthophyll lutein appeared relatively stable in anoxic muds and in oxygenated sand sediment over periods of weeks and months after deposition. This pigment may well remain intact throughout the horizontal transport from shallower areas, where the algae grow, down to the deep channels where the material is deposited. Its enhanced stability qualifies lutein as marker for red macroalgae in marine environments like Kiel Bight, where this algal group constitutes a major part of the phytobenthos. Investigation of pigment consumption and alteration by the marine bottom fauna are necessary, as the results reported here refer to conditions where the influence of the bottom fauna was artificially reduced (oxic sediment) or where bottom fauna was naturally scarce (anoxic core).

Carotenoids in marine sediments deposited $10^{5}$ yr BP were reported by Watts \& Maxwell (1977). They found $\beta$-carotene to be stable in a deep-sea core from the Cariaco Trench off Venezuela in strata representing a timespan of $340000 \mathrm{yr}$. These authors were, however, interested in geochemical stability in deeper sediment strata, and not in pigment breakdown within the biologically active sediment layer. The same authors also report a high stability of the lutein isomer zeaxanthin, though this component degraded faster than $\beta$ carotene in the same core. We found the same differences of pigment stability, i.e. fast-degrading markers chlorophyll $a$, fucoxanthin and peridinin and slowdegrading $\beta$-carotene and lutein, in our comparatively young Kiel Bight surface sediments.

\section{How useful are pigment markers for in situ studies?}

Two different sediments in Kiel Bight were sampled for 1 yr to confirm the suitability of lutein as marker for red algae material in this area. The aim was to find a difference in temporal and spatial distribution between lutein and the phytoplankton marking pigments. It was expected that horizontally transported macrophyte debris is trapped in off-shore depressions and channels and accumulates in muddy sediments, whereas the phytoplankton sedimentation (fucoxanthin, peridinin) is of the same magnitude throughout.

The isomers lutein and zeaxanthin were not detected at the $12 \mathrm{~m}$ sand station, but formed the major pigment 
fraction in the mud sediment of the channel. Moreover, they differed completely from the phytoplankton pigments with regard to temporal distribution. While fucoxanthin, chlorophyll $a$ and peridinin peaked in spring and summer, marking sedimentation of phytoplankton blooms, lutein and zeaxanthin exhibited highest concentrations during autumn and winter. Accumulation of red macrophyte detritus in the organically rich deeper mud sediments is documented by continuously increasing lutein concentrations in the sediment at the $19 \mathrm{~m}$ station (Fig. 7) during late autumn and winter. The observed lutein accumulation correlates well with observations of the horizontal transport of macrophytes in field studies (Schomann 1977) and with recent underwater camera investigations as shown in Fig. 8 (Breuer 1989). Consequently, the

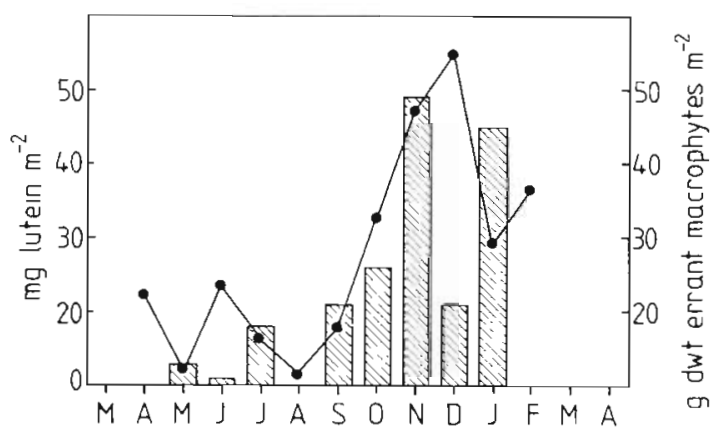

Fig. 8. Lutein concentrations $(-\bullet)$ in the sediment surface of the $19 \mathrm{~m}$ mud station in relation to mass transport of errant macrophytes into Boknis Channel from underwater camera profiles (bars, Breuer 1989) between April 1986 and March 1987

applicability of a pigment as a biogeochemical marker strongly depends on the composition of the source material encountered in the investigated area. Watts et al. (1975), comparing freshwater lakes with intertidal and off-shore marine sediments, described lutein as a universally distributed marker. In different environmental systems this pigment derives from different sources, e.g. from green and red algae, as well as from terrestrial plant material. In Kiel Bight, where green algae play little role in terms of biomass, this pigment has a more specific character, marking accumulation of macrophyte debris predominantly derived from red macroalgae. The deposits may also include seagrass material, with lutein as dominant xanthophyll, but as there are no extended seagrass meadows in Kiel Bight the estimated contribution of this source to the sediment lutein pool is low.

Lutein accumulation in the sediment of Kiel Bight is related to macrophyte input. Macrophyte leaf-fall and the formation of detritus during late autumn and winter coincide with increasing lutein concentrations in the muddy sediments of the $19 \mathrm{~m}$ station (Fig. 8). Fucoxanthin and peridinin reflect input from phytoplankton sources like diatoms and dinoflagellates respectively, and are rapidly degraded after deposition in the sediment surface.

Acknowledgements. This paper represents part of the author's thesis in the fulfilment of the requirement of the Dr rer. nat. at the Institut für Meereskunde an der Universität Kiel, Marine Botany Department. I thank Prof. Dr S. A. Gerlach for encouragement and valuable advice during the course of this work. Thanks are due to Dr W. Schramm and Prof. Dr J. C. Duinker for stimulating discussions (all Institut für Meereskunde, Kiel). I also thank Prof. Dr H. Theede (Universität Bremen) for kind support during the completion of the manuscript. I greatly appreciated the constructive advice of 3 anonymous reviewers. This work was funded by the Umweltbundesamt (Germany), contract No. 102 04215/17.

\section{LITERATURE CITED}

Abele, D. (1988). Carotinoide als biogene Marker für benthische Makroalgen im Sediment der Kieler Bucht. Ber. Inst. Meeresk. Univ. Kiel 183; 1-116

Abele, D., Schramm, W. (1989). Carotenoids as biomarkers for macrophyte derived detrital material in a shallow coastal water ecosystem. Topics in Mar. Biol. 53 (2-3): 315-318

Balzer, W. (1986). Forms of phosphorus and its accumulation in coastal sediments of Kieler Bucht. Ophelia 26: 19-35

Björnland, T., Aguilar-Martinez, M. (1976). Alkaline TLCplates. Phytochem. 15: 291-296

Breuer, G. (1989). Vegetationsstruktur, Biomasse und Produktivität der sublitoralen Rotalgengemeinschaften der Restsedimentgebiete in der Kieler Bucht. Dissertation, Universität Kiel

Breuer, G., Schramm, W. (1988). Changes in macroalgal vegetation of Kiel Bight (Western Baltic Sea) during the past 20 years - causes and consequences. Kieler Meeresforsch., Sonderh. 6: 241-255

Conover, R. J., Durvasula, R., Roy, S., Wang, R. (1986). Probable loss of chlorophyll-derived pigments during passage through the gut of zooplankton, and some of the consequences. Limnol. Oceanogr. 32: 878-887

Downs, J. N., Lorenzen, C. J. (1985). Carbon:pheopigment ratios of zooplankton fecal pellets as an index of herbivorous feeding. Limnol. Oceanogr 30: 1024-1036

Erlenkeuser, H., Suess, E., Willkomm, H. (1974). Industrialization affects heavy metal and carbon isotope concentrations in recent sediments. Geochim. Cosmochim. Acta 38: 823-842

Gieskes, W. W., Kraay, G. W. (1983). Dominance of Cryprophyceae during the phytoplankton spring bloom in the central North Sea detected by HPLC analysis of pigments. Mar. Biol. 75: 179-185

Gieskes, W. W., Kraay, G. W. (1984). Phytoplankton, its pigments and primary production at a central North Sea station in May, July and September 1981. Neth. J. Sea Res. 18: $51-70$

Gieskes, W. W., Kraay, G. W. (1986). Analysis of phytoplankton pigments by HPLC before during and after mass occurrence of the microflagellate Corymbellus aureus during the spring bloom in the open North Sea in 1983. Mar. Biol. 92: $45-52$ 
Graf, G. (1989a). Benthic-pelagic coupling in a deep-sea benthic community. Nature, Lond. 341: 437-439

Graf, G. (1989b). Die Reaktionen des Benthals auf den saisonalen PartikelfluB und die laterale Advektion, sowie deren Bedeutung für Sauerstoff- und Kohlenstoffbilanz. Habilitationsschrift, Mathematisch-Naturwiss. Fakultät, Universität Kiel

Klein, B., Gieskes, W. W., Kraay, G. (1986). Digestion of chlorophylls and carotenoids by the marine protozoan Oxyrhis marina by HPLC analysis of algal pigments. J. Plankton Res. 8: 827-836

Klein, B., Sournia, A. (1987). A daily study of the diatom spring bloom at Roscoff (France) in 1985. II. Phytoplankton pigment composition studied by HPLC analysis. Mar. Ecol. Prog. Ser. 37: 265-275

Kleppel, G. S., Pieper, R. E. (1984). Phytoplankton pigments in the gut contents of planktonic copepods from coastal waters off southern California. Mar. Biol. 78: 193-198

Lehmann, P. W. (1981). Comparison of chlorophyll a and carotenoid pigments as predictors of phytoplankton biomass. Mar Biol. 65: 237-244

Liebezeit, G. (1986). Pelagic and benthic sources of sedimentary carbohydrates in a shallow-water environment, Kiel Bight, Baltic. Mar. Geol. 71: 201-213

Mantoura, R. F. C., Llewellyn, C. A. (1983). The rapid determination of algal chlorophyll and carotenoid pigments and their breakdown products in natural waters by HPLC Analyt. Chim. Acta 151: 297-314

Nelson, J. R. (1989). Phytoplankton pigments in macrozooplankton feces: variability in carotenoid alterations. Mar. Ecol. Prog. Ser. 52: 129-144

Repeta, D. J., Gagosian, R. B. (1981). Carotenoid transformation products in the upwelled waters off the Peruvian Coast: suspended particulate matter, sediment trap material and zooplankton fecal pellet analysis. Adv. org. Geochem.: 380-388

Repeta, D. J., Gagosian, R. B. (1982). Carotenoid transformations in coastal marine waters. Nature, Lond. 295: $51-54$

Repeta, D. J., Gagosian, R. B. (1987). Carotinoid diagenesis in

This article was submitted to the editor recent marine sediments. I. The Peru continental shelf $\left(15^{\circ} \mathrm{S}, 75^{\circ} \mathrm{W}\right)$. Geochim. Cosmochim. Acta 51 1001-1009

Riaux-Gobin, C., Llewellyn, C. A., Klein, B. (1987). Microphytobenthos from two subtidal sediments from North Brittany. II. Variations of pigment compositions and concentrations determined by HPLC and conventional techniques. Mar. Ecol. Prog. Ser. 40: 275-283

Schomann, H. (1977). Qualitative and quantitative Untersuchungen an der erranten Vegetationskomponente im Phytobenthos der Westlichen Ostsee. Diplomarbeit, Universität Kiel

Smetacek, V., von Bodungen, B., Knoppers, B., Peinert, R. Pollehne, F., Stegmann, P., Zeitzschel, B. (1984). Seasonal stages characterizing the annual cycle of an inshore pelagic system. Rapp. P.-v. Réun. Cons. int. Explor. Mer 183: 126-135

SooHoo, J. B., Kiefer, D. A. (1982). Vertical distribution of pheopigments. Deep Sea Res. 29: 1539-1551

Wang, R., Conover, R. J. (1986). Dynamics of gut pigment in the copepod Temora longicornis and the determination of in situ grazing rates. Limnol. Oceanogr. 31: 867-877

Watts, C. D., Maxwell, J. R. (1977). Carotenoid diagenesis in a marine sediment. Geochim. Cosmochim. Acta 41:493-497

Watts, C. D., Kjosen, H., Maxwell, J. R. (1975). The potential of carotenoids as environmental indicators. Adv. org. Geochim.: 391-413

Wefer, G., Balzer, W., von Bodungen, B., Suess, E. (1987). Biogenic carbonates in temperate and subtropical environments: production and accumulation, saturation state and stable isotope composition. In: Rumohr, J., Walger, E., Zeitzschel, B. (eds.) Seawater-sediment interactions in coastal waters. Springer Verlag, Berlin, New York, p. 263-303

Wright, S. W., Jeffrey, S. W. (1987). Fucoxanthin pigment markers of marine phytoplankton analysed by HPLC and HPTLC. Mar Ecol. Prog. Ser. 38: 259-266

Züllig, H. (1982). Untersuchungen über die Stratigraphie von Carotinoiden im geschichteten Sediment von 10 Schweizer Seen zur Erkundung früherer PhytoplanktonEntfaltungen. Schweiz. Z. Hydrol. 44: 1-98

Manuscript first received: March 15, 1990

Revised version accepted: November 22, 1990 